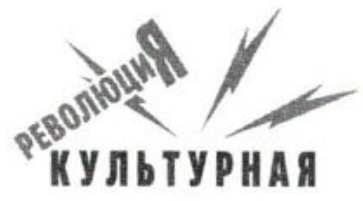


Институт философии

Российской академии наук

\title{
Фридрих Ницше
}

\author{
полное собрание \\ сочинений \\ в тринадцати томах
}

Редакционный совет

П.П. Гайденко, А. А. Гусейнов,

С. В. Казачков, В. Н. Миронов,

Н. В. Мотроиилова, Т. Н. Ойзерман,

B. A. Подорога, B. A. Попов,

К. А. Свасъян, Ю. В. Синеокая,

В. С. Стёпин, И. А. Эбаноидзе

\author{
Издательство \\ «Культурная Революция» \\ Москва
}


Институт философии

Российской академии наук

\title{
Фридрих Ницше
}

\author{
полное собрание \\ сочинений
}

Тринадиатый том

\author{
Черновики \\ и наброски \\ I $887-$ I 889 г2.
}

Перевод с немецкого

В.М.Бакусева и А.В.Гараджи

Издательство

«Культурная Революция»

Москва 2006 
ББК 87.3 Герм

$\mathrm{H}_{70}$

Сверка, научное редактирование С. В.Казачков

Перевод В.М. Бакусев (14 [8o] - 25 [21], послесловие),

А.В. Гараджа (11 [1] - 14 [79])

Оформление И. Бернштейн

\section{Нищше, Фридрих.}

Н7о Полное собрание сочинений: В 13 томах / Ин-т философии.-М.: Культурная революция, 2005-

T.13: Черновики и наброски 1887-1889rг. / Пер. с нем. В.М. Бакусева и А.В. Гараджи; науч. ред. С.В. Казачков.2006.-656 c.-ISBN 5-902764-12-2.

Предлагаемый перевод воспроизводит все содержание рабочих тетрадей Ницше последних полутора лет его сознательной жизни. Выполнен по немецкому академическому изданию под редакцией Д. Колли и М. Монтинари.

На русском языке издается впервые.

Издание этой книги осуществлено при финансовой поддержке Института им. Гете Die Herausgabe des Werkes wurde aus Mitteln des Goethe-Instituts gefördert

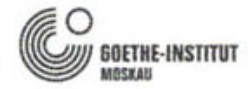

(c) Культурная Революция. 2006

Giorgio Colli/Mazzino Montinari, Nietzsche. KSA Vol. 13: Nachgelassene Fragmente 1887-1889

(c) 1988 by Walter de Gruyter GmbH \& Co. KG, Berlin. All rights reserved. ISBN 3-423-59044-0

Giorgio Colli/Mazzino Montinari

Nietzsche. KSA. Volume 14, Kommentar zu Band 1-13

(C) 1967-77 und 1988 (2., durchgesehene Auflage) by Walter de Gruyter GmbH \& Co. KG, Berlin. All rights reserved

(C) В. М. Бакусев. Перевод, 2006

(c) А. В. Гараджа. Перевод, 2006

(c) С. В. Казачков. Редакция перевода, 2006

() И. Бернштейн. Оформление, 2006 